вызывает определенные трудности у правоприменителя, в связи с чем данная категория нуждается в дальнейшей разработке.

1. Уголовный кодекс Российской Федерации от 13.06.1996 № 63-Ф3 // Собрание законодательства РФ. 17.06.1996. № 25. Ст. 2954.

2. П Постановление Пленума Верховного Суда РФ от 01.02.2011 № 1 (ред. от 29.11.2016) «О судебной практике применения законодательства, регламентирующего особенности уголовной ответственности и наказания несовершеннолетних» // Бюллетень Верховного Суда РФ. 2011. № 4.

3. Горбачева Е.В. Уголовно-процессуальное значение судебно-психологической экспертизы несовершеннолетнего обвиняемого // СибЮрВестник. 1998. № 1.

4. Дубровина И.В. Идеи Л.С. Выготского о содержании детской практической психологии // Электронный журнал «Психологическая наука и образование». 2013. № 3.

5. Пудовочкин Ю.Е. Ответственность за преступления против несовершеннолетних по российскому уголовному праву // Под ред. Чечель Г.И. - СПб: Юрид. центр Пресс, 2002.

\title{
Соловьева С.В., Аброян А.А. \\ Нецелевое использование бюджетных средств и средств государственных внебюджетных фондов: проблемы привлечения к административной ответственности
}

ФГБОУ ВО СКФ Российского государственного университета правосудия

doi: 10.18411/trnio-09-2021-86

(Россия, Краснодар)

\section{Аннотация}

Государственное регулирование финансовой сферы, несмотря на переход к рыночным отношениям, остается на сегодняшний день одним из важнейших элементов государственного управления. В статье рассматриваются проблемы привлечения к административной ответственности за нецелевое использование бюджетных средств и средств государственных внебюджетных фондов. В целях оптимизации процесса привлечения к ответственности за совершение указанного правонарушения предлагается внести ряд изменений в действующее российское законодательство.

Ключевые слова: целевое использование бюджетных средств, средства государственных внебюджетных фондов, административное правонарушение, административная ответственность.

\section{Abstract}

Government control of financial sphere, in spite of passing to the market relations, remains one of major state custom controls to date. In the article the problems of bringing in are examined to administrative responsibility for the no-purpose use of budgetary facilities and facilities of state offbudget funds. For optimization of process of bringing in to responsibility for the feasance of the indicated offence it is suggested to bring in the row of changes in the current Russian legislation.

Keywords: the having a special purpose use of budgetary facilities, means of state offbudget funds, administrative crime, administrative responsibility.

В действующем законодательстве за нецелевое использование бюджетных средств и средств государственных внебюджетных фондов наряду с ответственностью, установленной Бюджетным (ст. 289) и Уголовным (ст. 285.1, 285.2) кодексами РФ, в ст. 15.14 КоАП РФ предусмотрена административная ответственность.

Данное правонарушение посягает на общественные отношения в сфере финансового и кредитного регулирования, как в части использования средств бюджетов всех уровней, включая бюджеты субъектов Российской Федерации и местные бюджеты, так и в части использования средств государственных внебюджетных фондов [1]. 
При этом необходимо отметить, что, учитывая двойственность объекта правонарушения, в статье 15.14 КоАП РФ установлены два самостоятельных состава правонарушения.

1) Использование бюджетных средств получателем бюджетных средств на цели, не соответствующие условиям получения указанных средств, определенным:

- утвержденным бюджетом (т.е. основным финансовым планом соответствующей территории, который ежегодно утверждается в форме закона (федеральный бюджет, бюджет субъекта Российской Федерации) или в форме решения представительного органа местного самоуправления);

- бюджетной росписью (т.е. документом о поквартальном распределении доходов и расходов бюджета и поступлений из источников финансирования дефицита бюджета, устанавливающим распределение бюджетных ассигнований между получателями бюджетных средств и составляемом в соответствии с бюджетной классификацией РФ (ст. 6 Бюджетного кодекса РФ));

- уведомлением о бюджетных ассигнованиях (т.е. документом, в форме которого орган, исполняющий бюджет, доводит показатели бюджетной росписи до всех нижестоящих распорядителей и получателей бюджетных средств (ст. 220 Бюджетного кодекса РФ));

- сметой доходов и расходов (т.е. планом доходов и расходов бюджетного учреждения (ст. 221 Бюджетного кодекса РФ));

иным документом, являющимся основанием для получения бюджетных средств (таковым может быть соглашение о предоставлении бюджетных средств на возвратной основе, нормативный акт органа исполнительной власти либо органа местного самоуправления), если такое действие не содержит уголовно наказуемого деяния.

Соответственно, первый состав образует нецелевое использование именно бюджетных средств: средств федерального бюджета, бюджетов субъектов Российской Федерации и местных бюджетов. При этом для квалификации данного состава правонарушения необходимо установить еще и соответствие признаков деяния ст. 289 Бюджетного кодекса РФ, согласно которой нецелевое использование бюджетных средств выражается в направлении и использовании бюджетных средств на цели, не соответствующие условиям получения указанных средств, определенным утвержденным бюджетом, бюджетной росписью, уведомлением о бюджетных ассигнованиях, сметой доходов и расходов либо иным правовым основанием их получения.

2) Использование средств государственных внебюджетных фондов получателем средств государственных внебюджетных фондов на цели, не соответствующие условиям, определенным законодательством, регулирующим их деятельность, и бюджетам указанных фондов, если такое действие не содержит уголовно наказуемого деяния.

Второй состав образует нецелевое использование средств государственных внебюджетных фондов, к которым относятся средства государственных внебюджетных фондов и средства территориальных государственных внебюджетных фондов. Следовательно, для квалификации правонарушения по признакам ч. 2 ст. 15.14 КоАП РФ необходимо установить факт использования средств указанных фондов получателем средств на цели, не соответствующие условиям, определенным законодательством, регулирующим их деятельность (ст. 8 Федерального закона от 24.07.1998 № 125-Ф3 "Об обязательном социальном страховании от несчастных случаев на производстве и профессиональных заболеваний"; ст. 18 Федерального закона от 15.12.2001 № 167-Ф3 "Об обязательном пенсионном страховании в Российской Федерации и др.), и бюджетам указанных фондов. 
Целевое (или нецелевое) использование бюджетных средств всегда определяется в соотношении с целью выделения таких средств. Цель, в свою очередь, выводится из кода бюджетной (экономической) классификации, по которой доведены те или иные лимиты ассигнований и объемы финансирования.

Так целевое назначение, размер и направление использования средств определяются в сметах расходов и реестрах на перечисление бюджетных средств в разрезе функциональной и экономической классификации расходов бюджетов Российской Федерации главным распорядителем средств федерального бюджета, осуществляющим функции по управлению деятельности подведомственных ему учреждений. Каждая из статей расходов, являющихся структурным подразделением сметы, имеет предметно-целевое назначение, определяемое экономической классификацией расходов бюджетов. Из требований сметно-бюджетной дисциплины вытекает правило, согласно которому целевое назначение статей расходов не подлежит произвольному изменению. Фактически бюджетное учреждение вправе самостоятельно распоряжаться только денежными средствами, поступающими по определенной статье экономической классификации бюджетов и только в пределах данной статьи. По общему правилу перераспределение средств между статьями также не допускается. Права бюджетного учреждения по перераспределению расходов по предметным статьям и видам расходов при исполнении сметы определяются Федеральным казначейством РФ совместно с соответствующим главным распорядителем бюджетных средств. Если получатель средств неправильно классифицирует произведенные расходы и, следовательно, неправильно отражает их за счет какой-либо статьи бюджетной классификации, такая ошибка приведет к нарушению законодательства в виде нецелевого использования бюджетных средств [2].

Обязательным признаком объективной стороны рассматриваемых деяний является отсутствие признаков уголовно наказуемого деяния, т.е. отсутствие признаков составов преступлений, предусмотренных ст. 285.1 «Нецелевое расходование бюджетных средств» и ст. 285.2 «Нецелевое расходование средств государственных внебюджетных фондов» УК РФ. Проанализировав указанные составы преступлений, можно выделить признаки, позволяющие отграничить их от рассматриваемых составов административных правонарушений: это совершение деяния в крупном или особо крупном размере (крупным размером в ст. 285.1 и 285.2 УК РФ признается сумма бюджетных средств или средств государственных внебюджетных фондов, превышающая 1,5 млн. руб., а особо крупным размером - 7,5 млн. руб.), а также совершение деяния группой лиц по предварительному сговору. Таким образом, для квалификации деяния по ст. 15.14 КоАП РФ необходимо установить, что сумма бюджетных средств или средств государственных внебюджетных фондов, использованных по нецелевому назначению, менее 1500000 руб. и деяние не совершено группой лиц по предварительному сговору.

$$
* * *
$$

1. Определение Конституционного Суда РФ от 08.04.2004 № 137-О «Об отказе в принятии к рассмотрению запроса законодательного собрания Ростовской области о проверке конституционности ст. 15.14, 15.15, 15.16 и 23.7 Кодекса Российской Федерации об административных правонарушениях» // Вестник Конституционного Суда РФ. 2004. № 6.

2. Крохина Ю.А. Некоторые проблемы судебной практики привлечения к ответственности за нецелевое использование бюджетных средств // Вестник Арбитражного суда г. Москвы. 2006. N 3. 